\title{
The Sustainability of Independent Palm Oil Smallholders in Multi-Tier Supply Chains in East Kalimantan Indonesia
}

\author{
Fakhrizal Nashr ${ }^{1 *}$, Eka Intan Kumala Putri ${ }^{1}$, Arya Hadi Dharmawan ${ }^{2}$, Akhmad Fauzi $^{1}$ \\ ${ }^{1}$ Regional Development Planning and Rural Sciences, IPB University, Bogor 16680, Indonesia \\ ${ }^{2}$ Department of Communication and Community Development Sciences, IPB University, Bogor 16680, Indonesia
}

Corresponding Author Email: fakhrizal_nashr@apps.ipb.ac.id

https://doi.org/10.18280/ijsdp.160418

Received: 2 April 2021

Accepted: 18 June 2021

\section{Keywords:}

multi-dimensional scaling, multi-tier supply chain's management, sustainable palm oil, triadic relationships

\begin{abstract}
The smallholder oil palm farmers (SHFs) manage almost half of the Indonesian oil palm area, often associated with unsustainable oil palm sources. There has been limited research conducted to assess SHFs status in Indonesia. This study analyzed sustainability of existing Multi-tier Supply Chain Management through Rapfish diagnostic application with MultiDimensional Scaling (MDS) in oil palm mills, suppliers, and SHFs. This study found triadic typologies of MSCs in the Kutai Kartanegara District and six sustainability dimensions including economic, social, ecology, political, and institution to improve the regional strategy for sustainable palm oil plantations in the East Kalimantan Province. The closed triadic relationship in Gunung Sari and Pulau Pinang Villages has better performances on four sustainability dimensions compare to other villages. The oil palm mills could connect directly with SHFs and reduce asymmetric information and rent-seeking behavior through the traceable land ID system and enabling the Public-Private Partnership program.
\end{abstract}

\section{INTRODUCTION}

Palm oil is one of the most productive and profitable commodities for the past two decades in industrial food, oleochemicals, pharmaceutical, and energy for Indonesia [1, 2]. Demand for Crude Palm Oil (CPO) globally has increased drastically in the past ten years, followed by the peak of oil palm expansion just before COVID19 lockdown in early 2020 [3]. The most considerable growth is in Indonesia and Malaysia, with total production amounting to $95 \%$ of world demand and contributing to regional economic development [4]. Although Large-Scale Private Estates (Perkebunan Besar Swasta or PBS) still dominates palm oil production, smallholders have a salient position in producing Fresh Fruit Bunches (FFBs) palm oil. In 2020, total area of oil palm plantation was 14,97 million hectares with 6.09 (40.62\%), 8,26 $(55.09 \%)$ and $0.64(4.29 \%)$ million hectares is managed by smallholders, Private Plantation (PBS) and Large-Scale Stateowned Estates (Perkebunan Besar Negara or PBN) respectively [5]. Smallholders produced $35.38 \%$ or 17,38 million tons from the total Crude Palm Oil (CPO) production of 49,12 million tons.

The SHFs are expected to exceed PBS in the scale of areas and production in the future [6]. However, recent studies show that smallholder plantations' productivity is below plantation standards $[5,7,8]$. The annual productivity of smallholder plantation is around 11 tons FFB ha ${ }^{-1}$ and 1,6 tons of CPO $\mathrm{ha}^{-1}[5,9,10]$. Much lower than PBS annual productivity that can reach 30 tons of FFB ha ${ }^{-1}$ and 2-3 tons of CPO ha-1 $[5,10$, 11]. Indonesian $\mathrm{CPO}$ production and exports are increasing progressively as one of economically valuable commodities. The complexities of Multi-tier Supply Chain (MSC) including marketing network structure issues such as the number of nodes, reverse loops and multi-path exchanges, and behavioral problems such as non-linear dynamics, co-evolution, and emergence, are the research concerns in conducting sustainability diagnostic from SHFs, suppliers, and Palm Oil Mill. Typology of MSCs shows similar relationship between rural-urban linkages $[12,13]$ and relational capital in rural territorial capital [14-16] to supply-chain actors in oil palm commodities and $\mathrm{CPO}$ production through information and capital exchange $[12,13,17]$. The more reciprocal and closer relationship between actors, the stronger the rural-urban linkages and relational capital will be. Lewis's economic development model makes territorial capital shrink, while the network model development economy makes territorial capital stronger between rural resources, private, labor, and local community [18]. The concept was proposed in $O E C D$ Territorial Outlook in 2001 [14, 16] and territories is conceived as multi-dimensional spaces, where each dimension represents the presence of stocks of single types of territorial capital including location, size, quality, internal and external interactions. Relationships of a functional, hierarchical or cooperative nature may take place within the single dimension (economic, social, environmental, institutional, technological and political) or among the different dimensions, generating huge and diversified cross-externalities and synergy effects. Territorial development policies should first and foremost help areas to develop their territorial capital $[14,16]$. The MSCs typology classified the complexity of stakeholders and its relationships along the length of palm oil supply chain using triadic supply chain model to approach the complexity by recognizing three-tier system or triads in the village and inter village $[19,20]$. MSCs relationship becomes the new archetype of sustainability within social and environmental thresholds that enable rural territorial capital to leverage in a 
global position and how oil palm industry can position for it with stronger supply chain sustainability values $[19,20]$.

A sustainable and efficient supply chain can maximize the utility of limited available resources and minimize the risks of social, economic, and environmental impacts that may occur [21-27]. The relative condition of the SHFs supply chain often does not pay attention to the volume and risk assessment of the supply from Non-Deforestation, Peat, and Exploitation areas in the upstream part of the plantation that meets Green Procurement Production standards [19, 28]. The FFBs' supply chain complexity has implications at the processing industry's level at the downstream from the target market industry and the final consumers represented by brands and retailers who still question the credibility of sustainability issues $[29,30]$. Supply chain issues are further related to sustainability standards from the economic, ecological, social, institutional, technological, and political dimensions. Its primary attention of sustainability standard assessment is particularly paid to the SHFs supply chain, which often results in negative externalities at the village level $[31,32]$.

In addition, supply of oil palm commodities nationally and globally has created a fragmented and complex multi-tiered supply chain. Long and complex supply chains impact the performance of economic indicators such as cost, quality, reliability of supply, and resilience of SHFs [20, 31]. The supply chain's impact also occurs outside the economic sphere both environmentally and socially through the supply chain level [32, 33].

The complexity of multi-tiered supply chains is closely related to network structure problems such as several links, reverse loops, multi-channel exchange, and issues related to behavior such as non-linear dynamics and self-regulation, emergence, and co-evolution [20,34]. This article will explore a more in-depth on the understanding of the structure, behavior, and performance of a multi-tiered supply chain in the smallest unit network form, which allows for an analysis of the thirdparty impact on a relationship between two other institutions from the village level to the mills. We focus our study on two objectives including to understand typology of MSCs relationship existing in the landscapes and to assess sustainability status based on six contributing dimensions as applied along the palm oil supply chain.

\section{METHODS}

In this study, we used the approach for diagnostic Rapid Appraisal (RAP), which is often known by RAPFISH (RAP Fisheries) [35-37]. RAP tool has been tested with various complex cases and requires aspects of sustainability. RAP can determine the sustainability status on a scale of $0-100$. The diagnostic was conducted through multidisciplinary dimensions including economic, environmental, social, institutional, technological, and political. Formulations of input and output scores were simple, robust, and replicable. RAP uses the MCA (Multi-Criteria Analysis) appraisal method. Ordination technique was done through perceptual mapping with non-parametric MDS and entering good, bad, or ugly 'anchor points.' Analysis can reveal leverage and we handled uncertainty through 'Monte Carlo' analysis [38].

In this study, we collected data from six villages in Kutai Kartanegara District of East Kalimantan Province. The study used both primary and secondary data. Surveys and in-depth interviews were conducted to collect primary data at the village level. Interviews were carried out in six villages including Gunung Sari, Pulau Pinang, Sabintulung, Muara Kaman Ulu, Kutai Lama, and Handil Terusan. Data collection was carried out from 2018 to 2019.

Approaches to research and data analysis were made by analyzing the sustainability along the supply chain starting from SHFs, traders in the village, inter-village traders, cooperatives, and oil palm mills (OPM). The results of the analysis were then formulated into the typologies of the supply chain in the context of rural territorial and rural-urban linkages.

\subsection{Data analysis}

The study proposes a triadic approach as a fundamental building block of a network to solve supply chain complexities [20]. Triadic perspectives include social network theory, balance theory, the intermediary role, and the relation of rural territorial capital. This approach helps research the supply chain's social aspects, exploring suppliers' and buyers' dynamics (Table 1). The research paid attention on the supplier-supplier-buyer relationship that involved two suppliers and an oil palm mill as an end buyer. The supply chain formation uses a premise that the company has grown beyond the suppliers and aims to manage suppliers' network as a resource sustainably. In which, the strength of the network represents the performance of the supply chain operation.

Figure 1 showed the structure of MSCs for three supply chain cases in Kutai Kartanegara District. Open Triad represents the traditional supply chain when the flow of information and FFBs occur in a linear form of chain. There is no direct relationship between the oil palm mill and SHFs by setting cooperative as a mediator. A closed triad occurs when the oil palm mill and the SHFs have built a formal relationship connected directly, exchanging information, and managing relationships informal (through contracts) and informal interaction (routine meetings). The open and closed triad structure called the transitional triad when they started to build a connection between the oil palm mill, cooperatives, and the SHFs and build a relationship with the closed triad. In this structure, the SHFs stretch out each other and begin building a link and initiating a move toward closed MSCs.

Table 1. Approaches to research and data analysis uses in field

\begin{tabular}{cccc}
\hline No & Objective & Approach & Data Analysis \\
\hline 1 & $\begin{array}{c}\text { Formulating typology of Multi- } \\
\text { tiers Oil Palm Supply Chains }\end{array}$ & $\begin{array}{c}\text { Non-survey (3 FGDs and in-depth interview with } \\
\text { farmers, traders, cooperatives and oil palm mills) }\end{array}$ & Descriptive qualitative \\
\hline \multirow{2}{*}{$\begin{array}{c}\text { To analyze the sustainability of } \\
\text { SHFs Oil Palm Supply Chain }\end{array}$} & $\begin{array}{c}\text { Son-survey (30 FHFs in 6 villages) } \\
\text { and in depth interview with farmers, traders, } \\
\text { cooperatives dan oil palm mills) }\end{array}$ & $\begin{array}{c}\text { Rapid Appraisal before and after } \\
\text { Provincial Government Regulation Year } \\
\text { 2018 on Sustainable Plantation }\end{array}$ \\
\hline
\end{tabular}




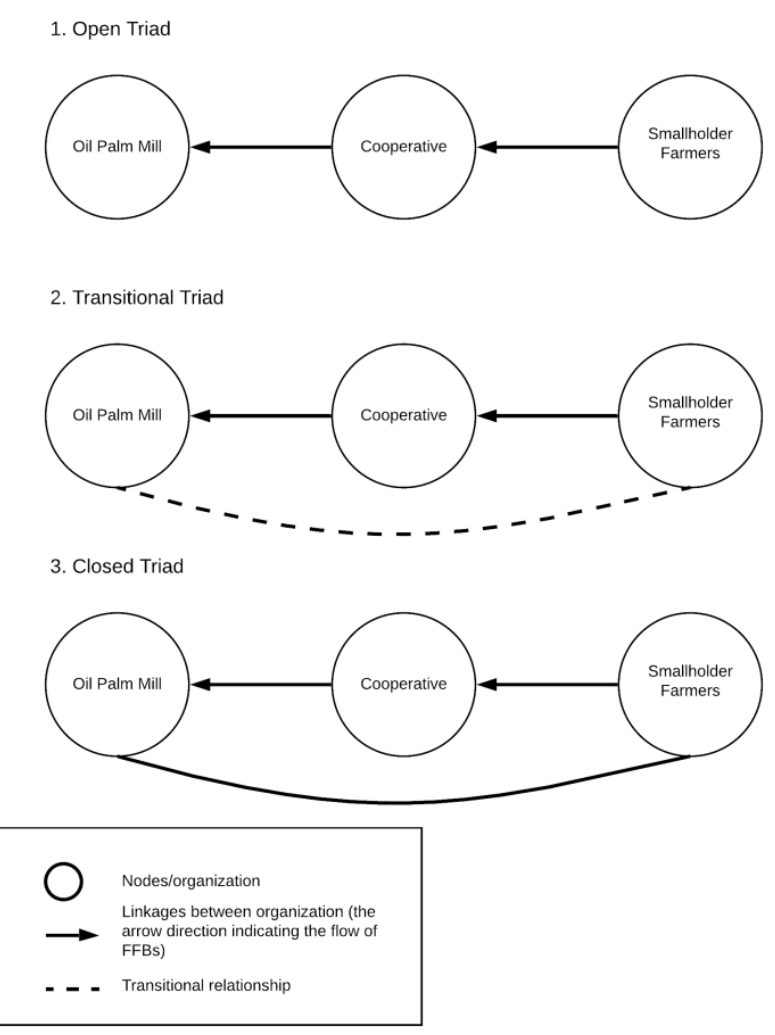

Figure 1. Oil palm multi-tier supply chain

The oil palm MSCs are important to understand the complex sustainability issues considering the triadic relationships and dynamics among supply chain actors in six villages. The dynamic of FFB's sourcing from smallholders and distribution system up to the oil palm mill are useful to see the impact of decision making and feedback control system in rural development $[33,34]$.

Further data analysis was done using RAP for Fisheries (RAPFISH) 2016 versions R through scoring against the attributes of supply chain sustainability that have been determined by using monotonic value with 0 minimum as bad criteria and 10 equal to good criteria $[35,37]$. Assessment of the supply chain were applied from supplier's supplier, supplier to oil palm mills going through applying six sustainability dimensions to get ordinance, leverage, and value of Montecarlo [37].

RAPFISH used the rules of multi-criteria with MultiDimensional Scaling (MDS) algorithms. MDS maps the perception distance between one unit and another with a scaling. It was assumed that SHFs faced the phenomenon of sustainability in a multi-dimensional situations. The RAPFISH rule could help find variables that might be used as leverage of sustainability. The output was carried out through rapid, information-based assessments by the ordinated scale of bad or good sustainability that meets the rules of conformity dimensions and variables. The number of dimensions of which were analyzed should be more than the variable $(n>v)$ and score allows the value of good and bad. Variables with the value of $>6$ might get ordinated as good, contrarily attributes are rated as bad. The goodness of fit is determined through the stress of indicator MDS $\leq 0.005$.

RAPFISH uses the ALSCAL MDS algorithm. MDS transforms multi-dimensional statistics into a lower dimension while maintaining the properties of the distance between variables. The MDS ALSCAL algorithm uses an alternating least-squares algorithm to perform multi-dimensional scaling
(MDS) and generates unit scores into the following two formulas [34].

$$
\zeta\{\mathrm{S}\}=D^{2}+\mathrm{E}
$$

$\zeta$ describes the monotonic transformation, $\mathrm{E}$ as a residual matrix, and D Euclidean matrix.

$$
\begin{gathered}
D^{2}=\sqrt{\left(Y_{1}-Y_{2}\right)^{2}+\left(Y_{3}-Y_{4}\right)^{2}+\ldots} \\
D^{2}=\sqrt{\sum_{i=1}^{n} \quad\left(Y_{i}-Y_{j}\right)} \quad \mathrm{i} \neq \mathrm{j}
\end{gathered}
$$

ALSCAL algorithm use iterative process to minimize $\mathrm{E}$ error and obtain goodness of fit with s-stress under 0.005 :

$$
\begin{gathered}
\text { S-Stress }=(\text { Stress })^{1 / 2} \\
\text { Stress }=\frac{\|E\|}{\|\zeta\{S\}\|}
\end{gathered}
$$

The double bar symbol or $\|.$.$\| is defined by the addition$ of matrix element $\mathrm{E}$ and $\mathrm{S}$.

The research and data analysis approach were made by analyzing the sustainability along the supply chain starting from SHFs, traders in the village, inter-village traders, cooperative, and oil palm mills. The analysis results then formulated into the typologies of the supply chain.

\section{RESULTS AND DISCUSSIONS}

\subsection{Multi-tiers supply chain typology}

We found three different typologies across six villages. Kutai Lama and Handil Terusan was observed as open triad while Muara Kaman Ulu and Sabintulang was under transitional triad. Closed triad was identified in Gunung Sari and Pulau Pinang. Majority of smallholders' productions were sold to local trader with only two villages have traded their commodities directly to oil palm mills including Gunung Sari and Pulau Pinang. Mechanism of pricing varies among the villages from asymmetric market price to regulated price from provincial authority.

The research compared case studies showing three similar dominant themes in six villages upstream to downstream of the district landscape. The theme in question concerns power structures, interdependence, and stable relations.

This study found within the six villages triadic relationship of SHFs, local traders, cooperatives and oil palm mills participating in the three-tier supply chain and their relationship. Seven distinguishing aspects define three MSCs typologies from open triad, closed triad and transitional triad (Table 2).

\subsubsection{Kutai Lama and Handil Terusan Villages}

SHFs sell FFBs to local trader under informal partnership. Prices follow unregulated deals with asymmetric market price. SHFs produce a non-standard FFBs quality and SHFs ignores the standard principles of GAP, mandatory ISPO and voluntary standard RSPO. Mills have establish relationship with the cooperative in term of quota of supplies but do not verified FFBs production. Mills without plantation competing to get supplier and outsourced the production capacity.Mills do not establish any direct relationship with the SHFs. There 
is no direct communication regarding the origin of seeds and seed certification. Mills do not commit to NDPE and do not implement traceability system. Likewise, SHFs do not comply with STDB and Forest Land status. Resulting uncertain connectivity and tensions between mills-SHFs with low added value.

Table 2. Distinguishing aspects of oil palm MSCs typology

\begin{tabular}{|c|c|c|c|}
\hline $\begin{array}{c}\text { Distinguishing } \\
\text { Aspects }\end{array}$ & Closed Triad MSC & Transitional Supply Chain & Open Triad MSC \\
\hline $\begin{array}{l}\text { FFB prices at } \\
\text { farm level }\end{array}$ & $\begin{array}{l}\text { Prices follow an orderly trade system } \\
\text { process in accordance with the agreement } \\
\text { in provincial level (government, } \\
\text { entrepreneurs and farmers) }\end{array}$ & $\begin{array}{c}\text { Price linkages between } \\
\text { smallholder farmers, local traders } \\
\text { and oil palm mills, are being } \\
\text { established }\end{array}$ & $\begin{array}{l}\text { Prices follow unregulated deals and } \\
\text { asymmetric market price }\end{array}$ \\
\hline $\begin{array}{l}\text { Information on } \\
\text { sustainable } \\
\text { palm oil } \\
\text { governance }\end{array}$ & $\begin{array}{l}\text { Palm oil production conforms to the } \\
\text { principles of the Good Agricultural } \\
\text { Practices (GAP) and Indonesia Sustainable } \\
\text { Palm Oil (ISPO) or Roundtable Sustainable } \\
\text { Palm Oil (RSPO) standards }\end{array}$ & $\begin{array}{l}\text { Tension between smallholder } \\
\text { farmers, local trader and oil palm } \\
\text { mills due to non compliance of } \\
\text { Principles and Criteria (P and C) } \\
\text { of sustainability standards } \\
\end{array}$ & $\begin{array}{l}\text { Palm oil production is non-standard } \\
\text { and ignores the standard principles of } \\
\text { GAP, ISPO or RSPO }\end{array}$ \\
\hline $\begin{array}{l}\text { Plantation } \\
\text { legality }\end{array}$ & $\begin{array}{c}\text { FFB production is carried out on } \\
\text { plantations on Non-Forest Area/Area } \\
\text { Peruntukan Lain (APL) or other-uses land }\end{array}$ & $\begin{array}{l}\text { Smallholder farmers and village } \\
\text { government initiate land use } \\
\text { planning to access land suitability }\end{array}$ & $\begin{array}{l}\text { Unverified FFB production, carried } \\
\text { out in non forest areas, concessions } \\
\text { and forest areas }\end{array}$ \\
\hline Seed legality & $\begin{array}{c}\text { Seed certification from an approved } \\
\text { government authority (Indonesian Oil Palm } \\
\text { Research Institue/PPKS, PT. Lonsum) }\end{array}$ & $\begin{array}{l}\text { Mixed use of certified seedlings } \\
\text { source }\end{array}$ & $\begin{array}{l}\text { There is no seed certification and the } \\
\text { origin of the seeds is not clear }\end{array}$ \\
\hline $\begin{array}{l}\text { Business } \\
\text { legality }\end{array}$ & $\begin{array}{c}\text { Farmers have complete Surat Tanda Daftar } \\
\text { Budidaya (STDB) documents (Cultivation } \\
\text { Registration Certificate) }\end{array}$ & $\begin{array}{l}\text { Smallholder farmers collect } \\
\text { information and apply STDB }\end{array}$ & $\begin{array}{c}\text { Farmers do not have STDB because } \\
\text { part of the land is in Forest Land } \\
\text { status }\end{array}$ \\
\hline Market certainty & $\begin{array}{l}\text { Certain supply chain connectivity with } \\
\text { palm oil mills and high added value }\end{array}$ & $\begin{array}{c}\text { Limited market access has } \\
\text { increased tensions and stimulated } \\
\text { supply chain connectivity } \\
\end{array}$ & $\begin{array}{l}\text { Uncertain connectivity and the SHFs } \\
\text { added value is low }\end{array}$ \\
\hline Traceability & $\begin{array}{l}\text { Good commodity traceability according to } \\
\text { sustainability standards }\end{array}$ & $\begin{array}{c}\text { Improving traceability by } \\
\text { connecting smallholder farmers } \\
\text { plot with village land use } \\
\text { planning }\end{array}$ & $\begin{array}{l}\text { Low traceability of products } \\
\text { according to sustainability standards }\end{array}$ \\
\hline
\end{tabular}

\subsubsection{Muara Kaman Ulu and Sabintulung Villages}

FFB production from SHFs was mainly sold to village trader. Price linkages between smallholder farmers, local traders and oil palm mills, are being established. There was tension between smallholder farmers, local trader and oil palm mills due to non-compliance of Principles and Criteria (P and C) of voluntary sustainability standards. Smallholder farmers and village government initiated land use planning to access land suitability. Mixed use of certified seedlings source. Smallholder farmers have collected necessary information and applied STDB. Limited market access has increased tensions and stimulated supply chain connectivity. Traceability can be improved by connecting smallholder farmers plot with village land use planning.

\subsubsection{Gunung sari and pulau pinang}

SHFs sell FFBs to three oil palm mills. Prices follow an orderly trade system process in accordance with the agreement in provincial level (government, entrepreneurs and farmers). Palm oil production conforms to the principles of the GAP, mandatory ISPO, and voluntary RSPO and ISCC standards. Cooperatives maintain good operational relationship to transport FFBs with corporate Land ID traceability system. Verified FFBs production is carried out only from Non-Forest Area (APL) with QR code controlling system. SHFs aware of seed certification from an approved government authority (PPKS, Lonsum, AA) and ISPO mandatory compliance. SHFs has a certain supply chain connectivity with palm oil mills and high added value. Mills maintain good communication through community development program and interesting to develop Public-Private-Partnership (PPP) program for replanting non-productive SHFs plantation.

\subsection{Sustainability of oil palm multi-tiers supply chain}

The diagnosis of the oil palm supply chain's sustainability status in the Kutai Kartanegara District was obtained from an analysis using the Multi-Dimensional Scaling (MDS) approach. The sustainability dimensions analyzed were based on the sustainability assessment [30] of economic, social, ecological, political, institutional, and the technological dimensions $[25,39,40]$. The application of sustainability principles and the linkage with the SHFs supply chain sustainability showed leverage analysis from three typologies to suppress externalities and anticipate market failures and to obtain a good palm oil supply.

\subsubsection{Open triad relationship}

The Rap-OPAL (Oil Palm Adaptive Landscape) sustainability diagnosis results are shown in the form of a kite diagram (Figure 3) and sustainability status diagram (Figure $8)$. The sustainability index for the environmental, political, and technological dimensions is classified as less sustainable. However, institutional (62.02), economic (73.07), and the social dimension (65.21) are categorized as quite sustainable. The SHFs sustainability index value for all dimensions was in an unsustainable position with the highest economic dimension score (32.69) and the social dimension (46.93). The six-dimensional sensitivity analysis shows the variables of oil palm demand, SHF's cooperative operational plans, environmental pollution, PPP cooperation, employment, and harvesting productivity as sensitive variables to increase sustainability (Figure 2).

The first supply chain case study consisted of independent SHFs, six inter-village traders, cooperatives, and oil palm mills. The mill purchases all FFBs from members of the 
Cooperative and several CV (Commanditaier Vennootschap) entities that have been awarded contracts in the form of Surat Perjanjian Kerja (SPK) or working agreement. The mill relies heavily on the supply of FFBs from the cooperative to meet the company's installed capacity. Fluctuations in price at the international market level affect the length of time for disbursement of payments to cooperative supplier partners. The mill-cooperative relationship is perceived negatively because of the lengthy time it takes to disburse from the mill to the cooperative. Some communities have further blocked roads to push delayed FFB payments.

The traders who are the SPK holders maintain direct relations with the SHFs through buying and selling transactions in the village. The oil palm plantations in Kutai Lama and Handil Terusan Villages are relatively new, so there are no traders from local villages. The six traders who buy FFB all come from neighboring villages or come from outside the village. Every trader does not make a formal contract to maintain relations. The perception of SHFs was negative for traders outside the village due to frequent delays in paying FFB to SHFs. The yield of FFB is marketed to mill by bearing transportation costs and the additional cost of grading.

The OPM provides market power to the SPK holders to deliver FFBs supplies to the companies of PT.S and PT.AJP who did not have a nucleus plantation. The supplier's perception of the mill is quite negative. One of the effects of late payment for 2-3 months could end up with the road closure demonstrations.

The mill has no relationship with SHFs regarding FFBs quality expectations and sustainability aspects in terms of plantation legality. There is asymmetric information between oil palm mill and SHFs although both need each other. Cooperatives and traders as intermediaries are required to provide transportation services and purchase transactions for FFBs. All intermediaries are outside the village and have information on the distribution of SHFs in Kutai Lama and Handil Terusan Villages. The mill does not know the existence and legality of SHFs. Cooperatives have not been formed in the village because there has not been a common understanding of the urgency of the FFBs trading arrangement. Figure 3 shows the sustainability kite diagram open triad MSCs.

In open triad supply chain, the presence of external trader in the village and lack of production standards were happened because the mills ignores sustainability commitment. Given this situation, it was very difficult for SHFs to progress with sustainability dimension and improving added value within the oil palm sector. This relationship in the long run is not strategic for village development and there is no incentive for improvement the oil palm sector or making linkages with public sector.

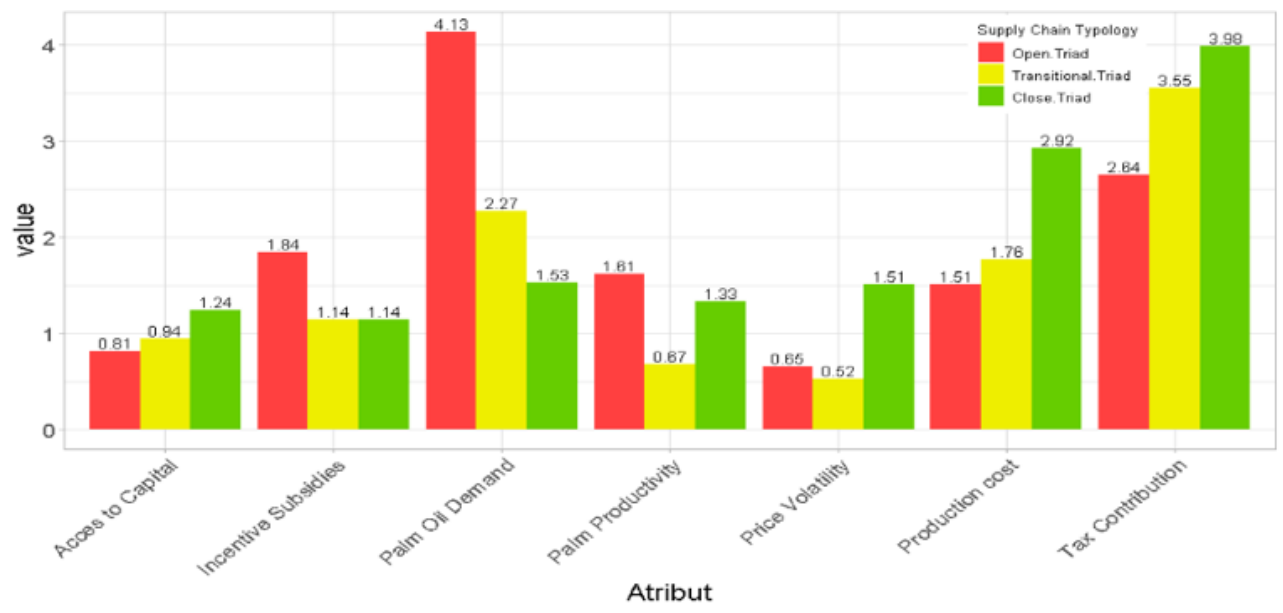

Figure 2. Economic dimension leverage analysis

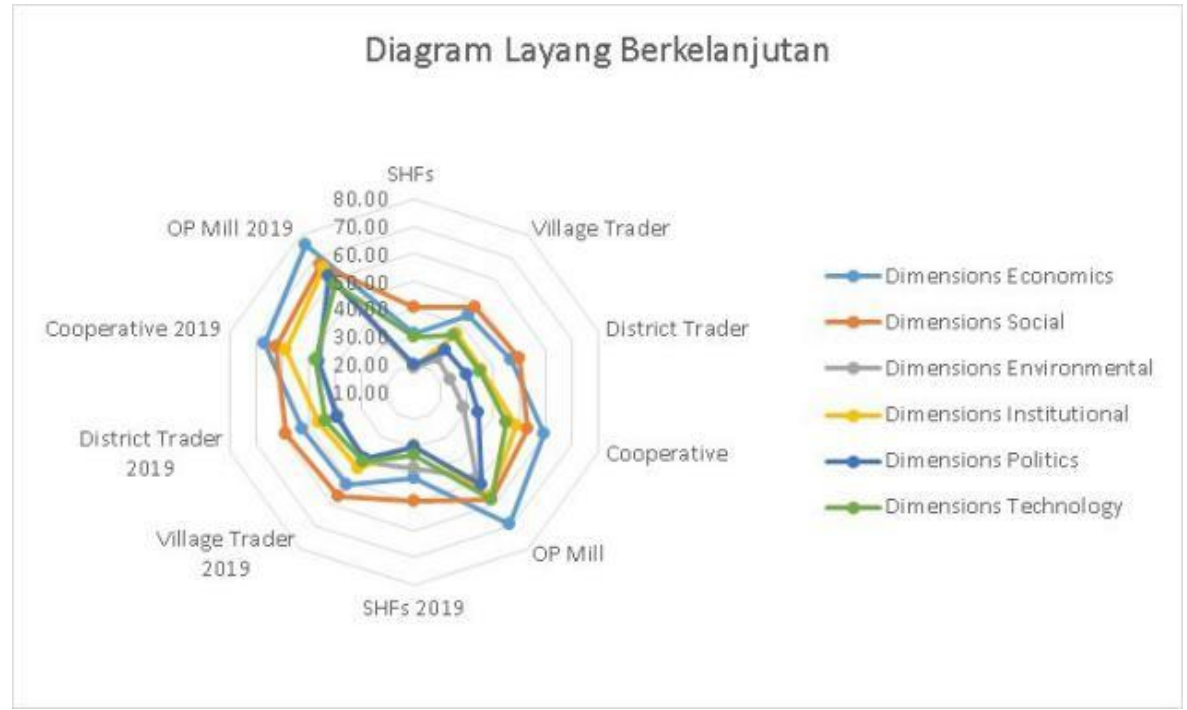

Figure 3. Sustainability kite diagram open triad MSCs 


\subsubsection{Transitional triad relationship}

The transitional triad sustainability index (Figure 5) is represented by Muara Kaman Ulu and Sabintulung villages' typology. The highest mills sustainability index is in the economic dimension (82.07) with a sustainable status, while the social and environmental dimensions are in a fairly sustainable status with scores of 64.27 and 66.95. Moderate score is shown by the institutional dimension, the political dimension, and the environmental dimension with values of $59.80,55.57$, and 56.79, respectively, which are in a fairly sustainable status. The SHFs sustainability index in transitional typology has a higher number than the open on the economic and environmental dimensions 39.21 and 39.91. The six-dimensional sensitivity analysis show the variables of tax contributions, information disclosure, fire prevention and control, oil palm financing, settlement of land disputes between residents, and GIS mapping as key variables leveraging changes in the transition of triad relations to closed relationships (Figure 4 and 5).

In this supply chain, the village trader appears to initiate communication between mills and SHFs. There has been growing interest also from the village government to facilitate SHFs through land use planning and this is in accordance with the results to resolve legality of land access for better sector development. The key transformation for transitional triad is to establish linkage between cooperative and the mills. Formal collaboration will improve awareness of voluntary certification standard compliance and GAP implementation. Both can improve land productivity and SHFs sector income.

\subsubsection{Closed triad relationship}

The MSCs typology uses triad relationships as the network's fundamental building block. Understanding how links affect other links and how nodes affect links that are not directly linked can unlock a network's essence. The following results describe the relationship typology of MSCs from the six villages, the sustainability ordinance in three typologies, and the sensitive attributes that lever the sustainability dimension. In Figure 1, the SHFs as a producer of FFBs material is in the weakest position because it has to bear all the sustainability risks with minimum knowledge on production standards, low oil palm productivity and income, lack of financial access, good social capital, direct relationship with off taker.

The sustainability index for closed triad MSCs show improvement of score index before and after provincial sustainable regulation in 2018. The sustainability index of SHFs, village trader and district trader are slightly lower than cooperative and oil palm mill. Sustainability index of economic dimension and institutional dimension indicate sustainable status comparing to political, environmental, technological and social dimensions.

The closed triad sustainability index (Figure 6) is represented by Gunung Sari and Pulau Pinang villages typology. The mill index is in a fairly sustainable status for the economic dimension alone, with a value of 71.75 . Five other dimensions are in a less sustainable status, such as the social dimension (61.56), institutional (67.92), politics (61.49), and technology (63.27).

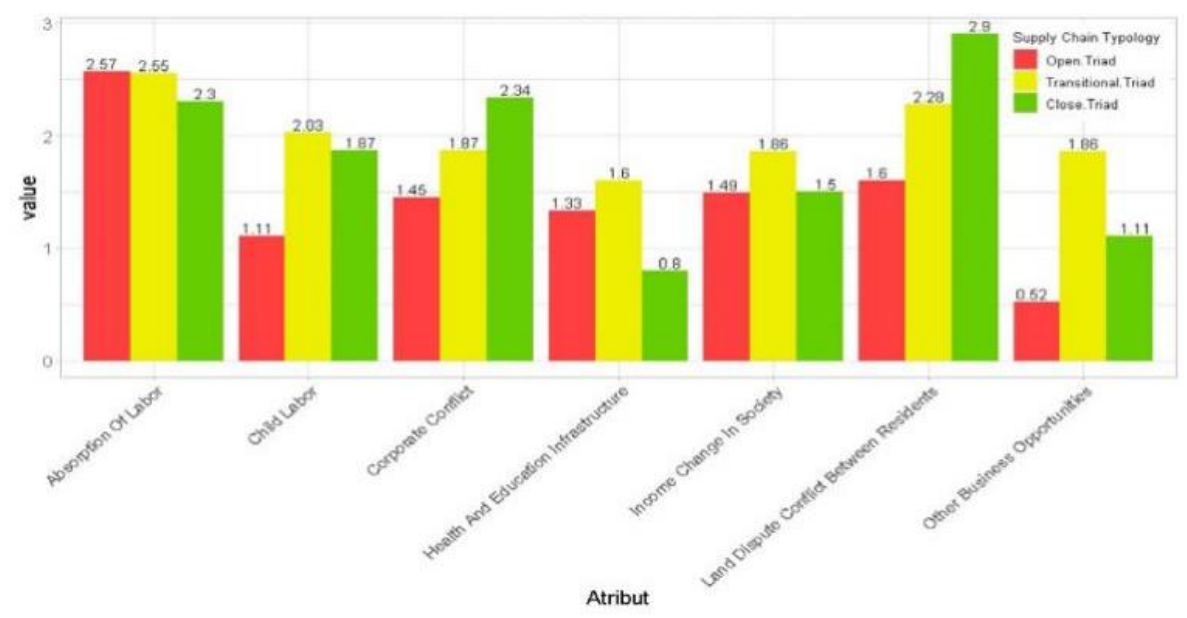

Figure 4. Social dimension leverage analysis

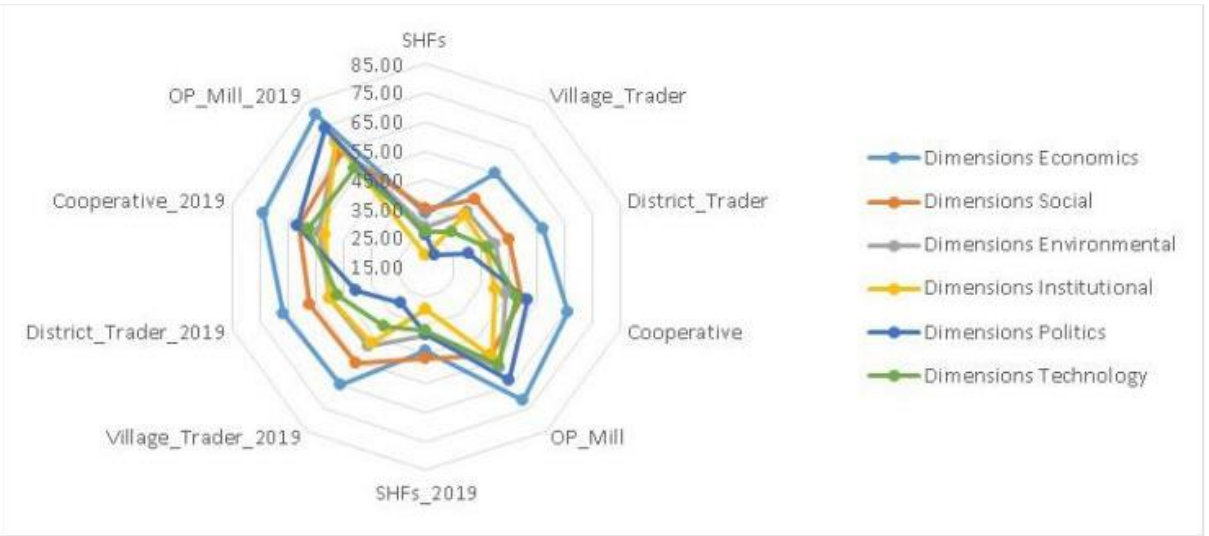

Figure 5. Sustainability kite diagram transitional triad MSCs 
The dimension with the lowest index score is the environmental dimension (Figure 7) with a value of 53.33. The six-dimensional sensitivity analysis shows the demand for oil palm, access to finance for cooperative, fire prevention and control, oil palm financing through BPDPKS (Badan Pengelola Dana Perkebunan Kelapa Sawit/Oil Palm Fund Management Agency), land resolution disputes between residents, and utilization of renewable resources as essential variables that can resolve sustainability issues in Gunung Sari and Pulau Pinang Villages.

The closed MSCs typology system for smallholders performs a salience position between six sustainability dimensions. As a consequence, that SHFs organizations must ensure better connectivity and relationships by creating a PPP road map. The six-dimensional sensitivity analysis helps to rethink oil palm demand by off-taker. Redesign the SHFs' cooperative operation plans and rebuild the existing plantation landscapes by minimizing environmental pollutions, primarily by lowering chemical herbicides and fossil fuel emissions.

The critical risk of enabling SHFs transformation is access to knowledge, information, and finance. Therefore, it is vital to build a sense of need for precise village data from a village level. Likewise, in district-level policy, such PPP can be leveraged through strengthening the relationship between SHFs and cooperatives, companies, government, agricultural extension workers, and financial institutions (rural-urban linkages).

\subsection{Six dimensions of sustainability status}

The six-dimensional ordinances positions are spread between bad and good with an index interval of 18.79-82.09 (Figure 8 and Figure 9). Leverage analysis (Figure 2, 4, and 7) shows sensitive attributes on each dimension that can affect the sustainability of independent smallholders.

In the economic dimension, the ordinance position is in the index range of 35.08-71.75. The most sensitive leverage attributes are palm demand for open triads and tax contributions for transitional and closed triads. Leverage demand for FFBs demand indicates a relationship that depends on the number of sales, even though the productivity and quality of independent smallholders are low. Meanwhile, the leveraged tax contribution shows a formal relationship between planters and cooperatives that positively impacts regional income.

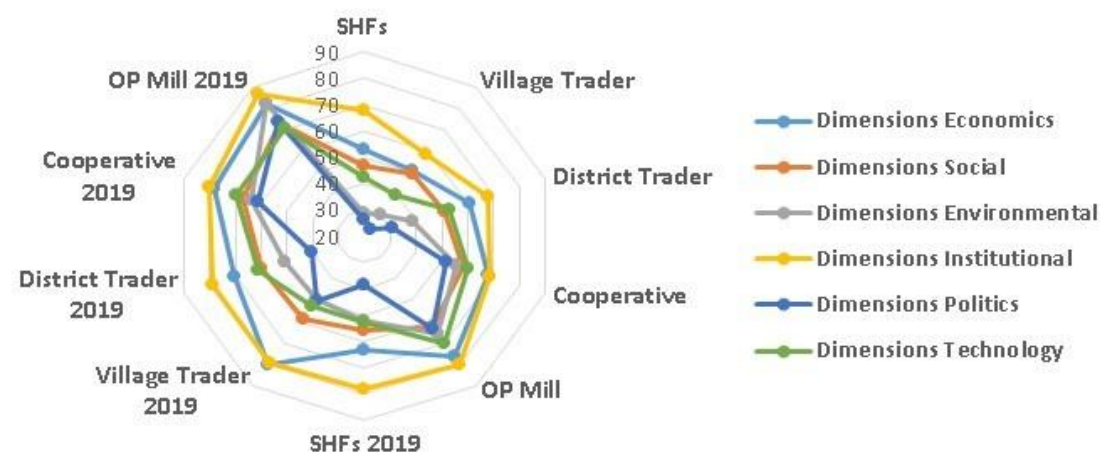

Figure 6. Sustainability kite diagram closed triad MSCs

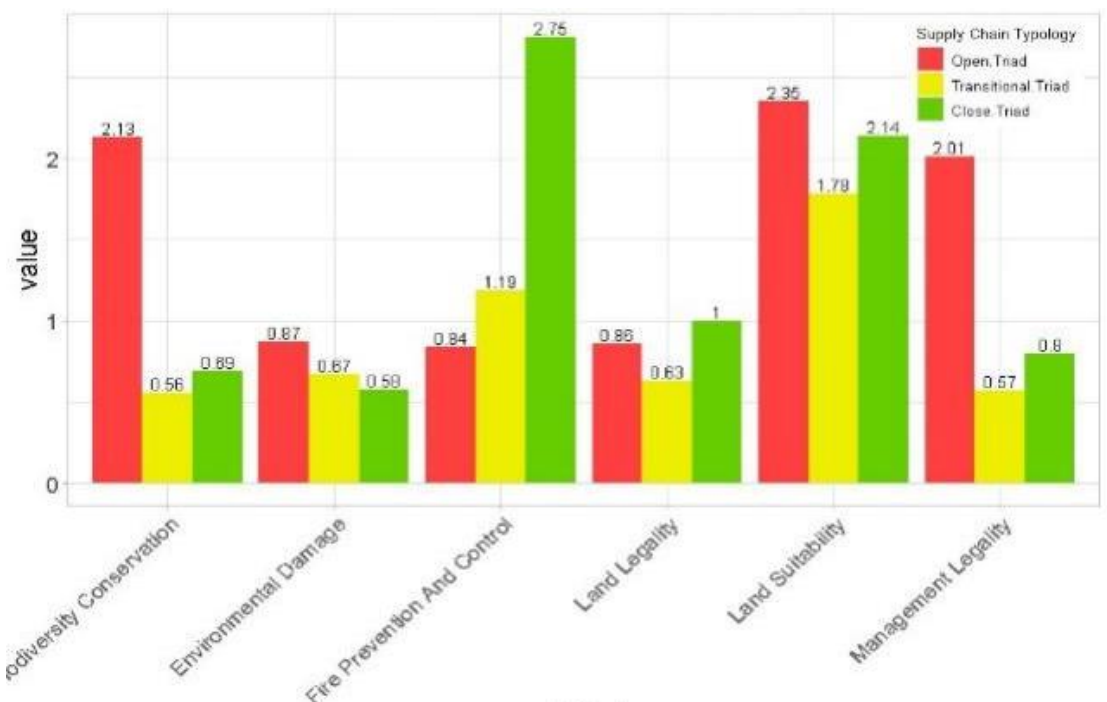

Atribut

Figure 7. Kite diagram environmental dimension 
Economics Dimension

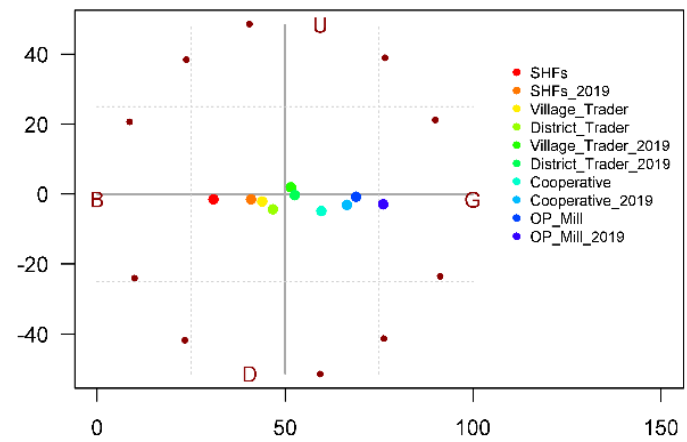

Politics Dimension

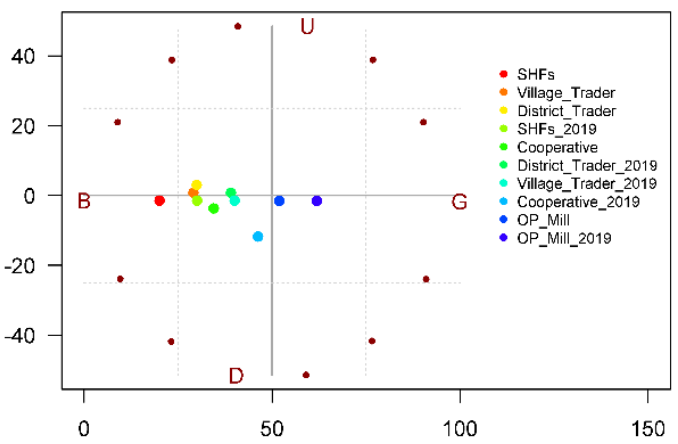

Environmental Dimension
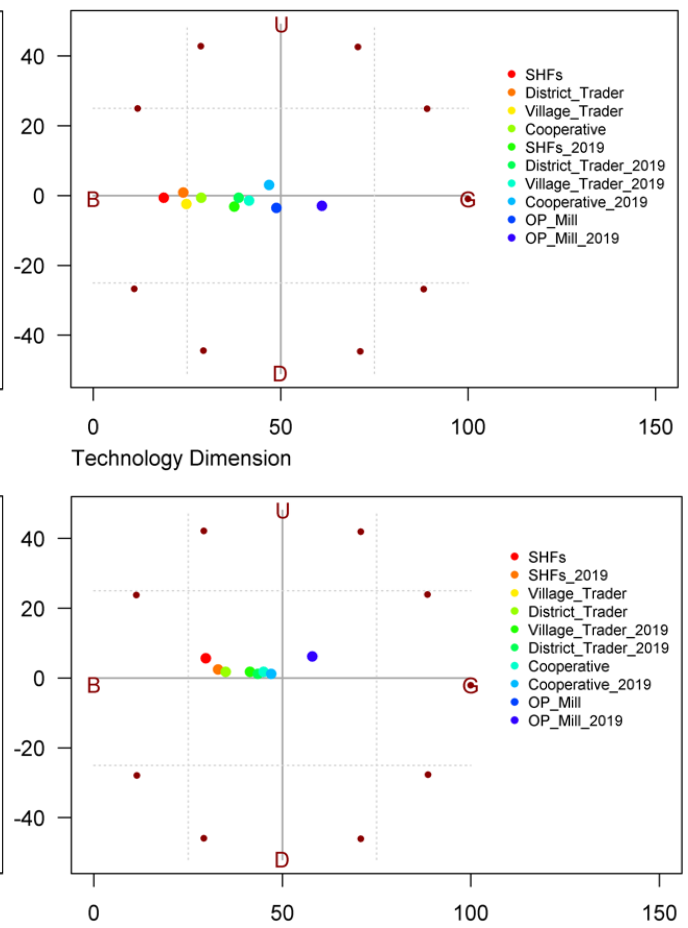

Figure 8. Sustainability dimension status of open triadic MSCs

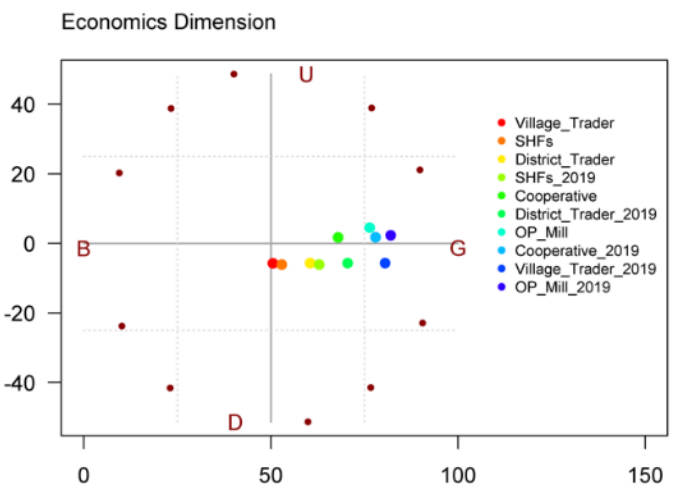

Environmental Dimension
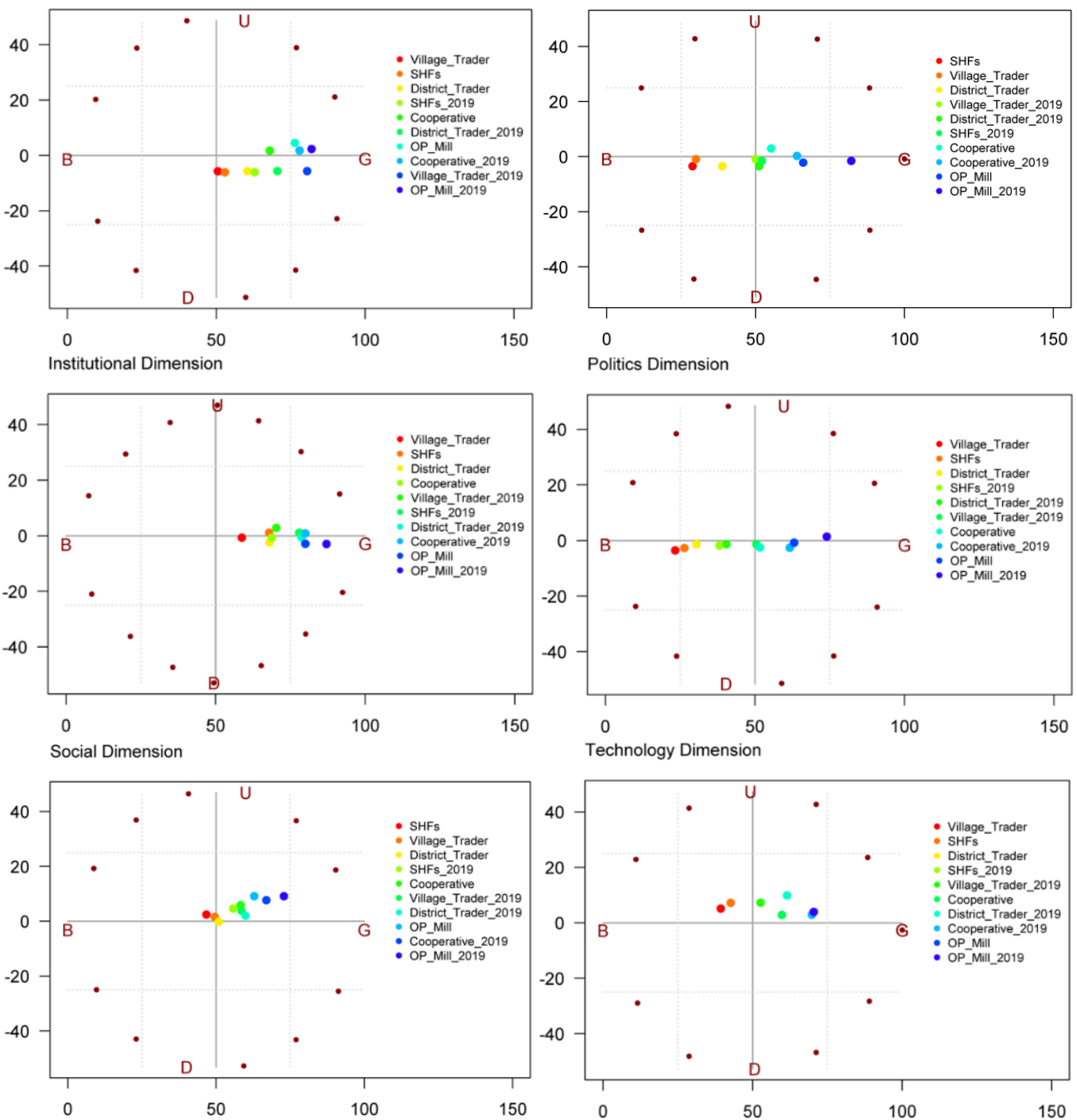

Figure 9. Sustainability dimension status of closed triadic MSCs 
In the open and transitional triad, the sensitive attribute of the social dimension is labor employment. Whereas in the closed triad, the sensitive attribute is more for handling land dispute conflicts between villagers. Independent smallholders in the middle and downstream Kutai District villagers are relatively new to developing the oil palm economy. Most of the maintenance of their palm plantation is carried out by family labor.

The environmental dimension ordinance result shows a value range of 18.79-82.09, with the distribution in the less sustainable to sustainable category. The sensitive attribute in the closed triad is fire prevention and control in areas with high conservation value. In contrast, the sensitive attribute in the transitional and open triad is land suitability. The FFBs traceability system from plantation to the mill has been well developed in the closed triad. Simultaneously, in the other two typologies, the sensitive attribute shows the urgency of reforming and establishing land use planning at the village level. The social dimension sustainability index is in the range of 35.28-72.86. The three typologies show fairly sustainable to sustainable social benefits to villagers.

The sustainability parameters priority from the highest sustainability ordinance starts from the institutional dimension, the economic dimension, the social dimension, the technological dimension, the environmental dimension, and the political dimension. Each dimension's leverage parameters are open information, tax contributions, resolution of land dispute conflicts between residents, harvesting productivity, fire prevention control, and PPP.

The transformation of the SHFs plantation sector occurs from open to transitional and closed triadic variables. Transforming of the SHFs plantation landscape needs to consider triadic supply chain relationships.

The first focus of oil palm SHFs is establishing a triadic relationship and using the market incentives to encourage continuous plantation productivity improvement. The second one is participatory village planning policy which helps resolve social conflicts between communities and land concession owners. The third is the sector organizes collective action on fire prevention on public goods and natural capital. The fourth one is open information to villagers regarding regulation and technical assistance. And the last one is effective producer organization (tax contribution) of the production base that can finance its operations and maintain sustainability.

\section{CONCLUSIONS}

Our study found that the major typology of Multi-Tier Supply Chains in East Kalimantan is triadic relationship of SHFs, local traders, cooperatives and oil palm mills participating in the three-tier supply chain. Majority of smallholders' productions were traded though intermediary buyers before reach oil palm mills. We propose transformation from open to close triadic relationship will improve the smallholders' performance in six sustainability dimensions and improve sector commodity added value. Reinvesting the added value to other crops and linking with PPP will be the path way for upstream-downstream agribusiness and rural economic development. The shift from open to closed triad leads to more positive relationships and multiplier effect, nature protection, and labor security. Lack of attention to these linkages will ignore the potential accessibility of rural communities to improve their livelihoods. On the contrary, it can increase industrialization, which encourages rural economic development.

The triadic supply chain structure is part of the interconnectedness of the global supply chains. The status quo tends to maintain rural poverty and its underdevelopment. Therefore, government policy should immediately strengthen rural market governance through improving landscapes sustainability. Otherwise, the palm oil economic growth will not reach maturity to reduce inequality in mutually reinforcing relationships.

Understanding the sustainability from the perspective of supply chain relationship offer multiple stakeholders to develop ways to improve relationship across multiple tiers including productivity and traceability of oil palm. We suggest that seven distinguish aspects developed by this study can be used as further reference to assess sustainability of the different supply chain typology.

\section{ACKNOWLEDGMENT}

The authors would like to thank to the Swiss National Science Foundation (SNSF) and to Oil Palm Adaptive Landscape (OPAL) research project, a collaboration between ETH-Zurich, the Center for International Forestry Research (CIFOR) and the Center for Agricultural and Rural Development Research of Bogor Agricultural University (IPB University), Indonesia. Special thanks are delivered to the oil palm farmers of the six villages: Kutai Lama, Handil Terusan, Muara Kaman Ulu, Sabintulung, Pulau Pinang and Gunung Sari to be open and were very supportive during the field research.

\section{REFERENCES}

[1] Mba, O.I., Dumont, M.J., Ngadi, M. (2015). Palm oil: Processing, characterization and utilization in the food industry-a review. Food Biosci. 10: 26-41. http://doi.org/10.1016/j.fbio.2015.01.003

[2] [BPS Provinsi Kaltim] Badan Pusat Statistik Provinsi Kalimantan Timur. (2018). Provinsi Kalimantan Timur dalam Angka 2018. http://www.kaltim.bps.go.id.

[3] FAO. (2020). Oil crops, oils and meals market assessment June 2020. https://www.fao.org/fileadmin/templates/est/COMM_M ARKETS_MONITORING/Oilcrops/Documents/Food_ outlook_oilseeds/Oilcrops_Oils_and_Meals_Food_Outl ook_2020.pdf.

[4] [BPDPKS] Badan Penglola Dana Perkebunan Kelapa Sawit. (2019). Kinerja Ekspor Sawit Triwulan I 2019. http://www.bpdp.or.id.

[5] [Dirjen Perkebunan] Direktorat Jenderal Perkebunan. (2020). Statistik Perkebunan Indonesia 1980-2020: Kelapa Sawit. Jakarta (ID): Kementerian Pertanian Republik Indonesia.

[6] Feintrenie, L., Levang, P. (2009). Sumatra's rubber agroforests: Advent, rise and fall of a sustainable cropping system. Small-Scale Forestry, 8: 323-335. https://dx.doi.org/10.1007/s11842-009-9086-2

[7] Euler, M., Schwarze, S., Siregar, H., Qaim, M. (2011). Oil palm expansion among smallholder farmers in Sumatra, Indonesia. Journal of Agricultural Economics, 
67(3): 658-676. http://dx.doi.org/10.1111/14779552.12163

[8] Jelsma, I., Woittiez, L.S., Ollivier, J., Dharmawan, A.H. (2019). Do wealthy farmers implement better agricultural practices? An assessment of implementation of Good Agricultural Practices among different types of independent oil palm smallholders in Riau, Indonesia. Agricultural Systems, 170: 63-76. http://doi.org/10.1016/j.agsy.2018.11.004

[9] Woittiez, L.S., van Wijk, M.T., Slingerland, M., van Noordwijk, M., Giller, K.E. (2017). Yield gap in oil palm: a quantitative review of contributing factors. Europ $\mathrm{J}$ Agron. 83 :

$57-77$. https://doi.org/10.1016/j.eja.2016.11.002

[10] Hoffmann, M.P., Donough, C., Oberthür, T., Castaneda Vera, A., van Wijk, M., Lim, C.H., Asmono, D., Samosir, Y., Lubis, A.P., Moses, D.S., Whitbread, A.M. (2015). Benchmarking yield for sustainable intensification of oil palm production in Indonesia using PALMSIM. The Planter, 91(1067): 81-96.

[11] Mafira, T., Rakhmadi, R., Hardjakusumah, C.N. (2018) Menuju rantai pasok kelapa sawit yang lebih berkelanjutan dan efisien di Berau, Kalimantan Timur. Climate Policy Initiative, Indonesia, 13-15.

[12] Friedmann, J., Douglass, M. (1978). Agropolitan development: Towards a new strategy for regional planning in Asia. Growth Pole Strategy and Regional Development Policy, 163-192. http://doi.org/10.1016/B978-0-08-021984-4.50014-9

[13] Douglass, M. (1998). A regional network strategy for reciprocal rural-urban linkages. An Agenda for Policy Research with Reference to Indonesia. TWPR, 20(1): 1 . http://dx.doi.org/10.3828/twpr.20.1.f2827602h503k5j6

[14] Capello, R., Caragliu, A., Nijkamp, P. (2011). Territorial capital and regional growth: Increasing returns in knowledge use. Journal of Economic and Human Geography, 102(4): $385-405$ https://doi.org/10.1111/j.1467-9663.2010.00613.x

[15] Camagni, R. (2016). Urban development and control on urban land rents. Annals of Regional Sciences, 56: $597-$ 615. https://doi.org/10.1007/s00168-015-0733-6

[16] Camagni, R. (2017). Territorial capital, competitiveness and regional development. Chapter 10 in Handbook of Regions and Competitiveness, 232-244. https://econpapers.repec.org/bookchap/elgeechap/15784 5f10.htm.

[17] Lakshmanan, T.R., Button, K.J. (2019). Institutions and regional development. Handbook of Regional Growth and Development Theories. Edward Elgar Publishing Limited. UK: Cheltenham. https://doi.org/10.4337/9781788970020

[18] Rustiadi, E., Saefulhakim, S., Panuju, D.R. (2017). Perencanaan dan pengembangan wilayah. Edisi kedua Jakarta: Yayasan Pustaka Obor Indonesia.

[19] Lyons-White, J., Knight, A.T. (2018). Palm oil supply chain complexity impedes implementation of corporate no-deforestation commitments. Journal of Global Environmental Change, 50: 303-313. http://doi.org/10.1016/j.gloenvcha.2018.04.012

[20] Mena, C., Humphries, A., Choi, T.Y. (2013). Toward a theory of multi-tier supply chain management. Journal of Supply Chain Management, 49(2): 58-77. https://doi.org/10.1111/jscm.12003

[21] Dharmawan, A.H., Mardiyaningsih, D.I., Rahmadian, F.,
Yulian, B.E., Komarudin, H., Pacheco, P., Ghazoul, J., Amalia, R. (2021). The agrarian, structural and cultural constraints of smallholders' readiness for sustainability standards implementation: the case of Indonesia Sustainanable Palm Oil in East Kalimantan. Journal Sustainability, 13(5): 2611. https://doi.org/10.3390/su13052611

[22] Dharmawan, A.H., Mardiyaningsih, D.I., Komarudin, H., Ghazoul, J., Pacheco, P., Rahmadian, F. (2020). Dynamics of rural economy: a socio-economic understanding of oil palm expansion and landscape changes in East Kalimantan, Indonesia. Journal of Land 9(7): 213. https://doi.org/10.3390/land9070213

[23] Dharmawan, A.H., Nasdian, F.T., Barus, B., Kinseng, R.A., Indaryanti, Y., Indriana, H., Mardianingsih, D.I., Rahmadian, F., Hidayati, H.N., Roslinawati, A.M. (2019). Kesiapan Petani Kelapa Sawit Swadaya dalam Implementasi ISPO: Persoalan Lingkungan Hidup, Legalitas dan Keberlanjutan. Jurnal Ilmu Lingkungan, 17(2): 304-315. https://doi.org/10.14710/jil.17.2.304315

[24] Widodo, K.H., Abdullah, A., Arbita, K.P.D. (2010). Sistem supply chain crude-palm-oil Indonesia dengan mempertimbangkan aspek economical revenue. Social Welfare dan Environment. JTI., 12(1): 47-54. https://doi.org/10.9744/jti.12.1.pp.\%2047-54

[25] Dharmawan, A.H., Fauzi, A., Putri, E.I.K., Pacheco, P., Dermawan, A., Nuva, N., Amalia, R., Sudaryanti, D.A. (2020). Bioenergy policy: The biodiesel sustainability dilemma in Indonesia. International Journal of Sustainable Development and Planning, 15(4): 537-546. https://doi.org/10.18280/ijsdp.150414

[26] Dharmawan, A.H., Mardiyaningsih, D.I., Rahmadian, F., Yulian, B.E., Komarudin, H., Pacheco, P., Ghazoul, J., Amalia, R. (2021). The agrarian, structural and cultural constraints of smallholders' readiness for sustainability standards implementation: the case of Indonesian sustainable palm oil in east Kalimantan. Journal of Sustainability, $13(5)$ : 2611. https://doi.org/10.3390/su13052611

[27] Santika, T., Wilson, K.A., Budiharta, S., Law, E.A., Poh, T.M., Ancrenaz, M., Struebig, M.J., Meijaard, E. (2019). Does oil palm agriculture help alleviate poverty? A multi-dimensional counterfactual assessment of oil palm development in Indonesia. Journal of World Development, 120: 105-117. https://doi.org/10.1016/j.worlddev.2019.04.012

[28] Larsen, R.K., Osbeck, M., Dawkins, E., Tuhkanen, H., Nguyen, H., Nugroho, A., Gardner, T.A., Zulfahm, Wolvekamp, P. (2018). Hybrid governance in agricultural commodity chains: Insights from implementation of 'No Deforestation, No Peat, No Exploitation' (NDPE) policies in the oil palm industry. Journal of Cleaner Production, 183: 544-554. https://doi.org/10.1016/j.jclepro.2018.02.125

[29] Susanti, A., Maryudi, A. (2016). Development narratives, notions of forest crisis, and boom of oil palm plantations in Indonesia. Forest Policy and Economics, 73: 130-130. https://doi.org/10.1016/j.forpol.2016.09.009

[30] Gibson, R.B., Hassan, S., Holtz, S., Tansey, J., Whitelaw, G. (2005). Sustainability Assessment: Criteria and Processes. New York (US): Taylor \& Francis. https://doi.org/10.4324/9781849772716

[31] Choi, T.Y., Krause, D.R. (2006). The supply base and its 
complexity: Implication for transaction costs, risks, responsiveness, and innovation for transaction costs, risks, responsiveness, and innovation. Journal of Operations Management, 24(5): 637-652. https://doi.org/10.1016/j.jom.2005.07.002

[32] Purnomo, H., Okarda, B., Dewayani, A.A., Ali, M., Achdiawan, R., Kartodihardjo, H., Pacheco, P., Juniwaty, K.S. (2017). Reducing forest and land fires through good palm oil value chain governance. Journal of Forest Policy Economics, 91: 94-106. https://doi.org/10.1016/j.forpol.2017.12.014

[33] Hsu, C., Choon, T.K., Hanim, M.Z.S., Jayaraman, V. (2013). Supply chain drivers that foster the development of green initiatives in an emerging economy. International Journal of Operations \& Production Management, 33(6): 656-688. https://doi.org/10.1108/ijopm-10-2011-0401

[34] Bowen, F.E., Cousins, P.D., Lamming, R.C., Faruk, A.C. (2001). The role of supply management capabilities in green supply. Production and Operations Management, 10(2): $\quad 174-189 . \quad$ https://doi.org/10.1111/j.19375956.2001.tb00077.x

[35] Fauzi, A. (2019). Teknik Analisis Berkelanjutan. Jakarta (ID): Gramedia.
[36] Kavanagh, P., Pitcher, T.J. (2004). Implementing Mircrosoft Excel Software for Rapfish: A technique for the Rapid Appraisal of Fisheries Status. Fisheries Centre Research Reports, https://doi.org/10.14288/1.0074801

[37] Pitcher, T.J., Lam, M.E., Ainsworth, C., Martindale, A., Nakamura, K., Perry, R.I., Ward, T. (2013). Improvement to Rapfish: A rapid evaluation technique for fisheries integrating ecological and human dimensions. Journal of Fish Biology, 83(4): 865-889. https://doi.org/10.1111/jfb.12122

[38] Stroh, D.P. (2018). Systems thinking for jurisdictional sustainability. The Nature Conservancy: Arlington, Virginia.

[39] Sokoastri, V., Setiadi, D., Hakim, A.R., Mawardhi, A.D., Dadli, M.L. (2019). Perkebunan petani kelapa sawit rakyat: permasalahan dan solusi. JSP. 07(3). https://doi.org/10.22500/sodality.v7i3.27221

[40] Sonief, A.A., Nuraini, Y., Setyabudi, S.A. (2019). Digitalisasi industri kecil dan produk pertanian daerah upaya untuk pemberdayaan masyarakat di Desa Karangbendo, Kecamatan Rogojampi Kabupaten Banyuwangi. J Inn Appl Tech. 5(1): 42-47. http://dx.doi.org/10.21776/ub.jiat.2019.005.01.5 